\title{
MONIKA MIAZEK-MĘCZYŃSKA
}

Uniwersytet im. Adama Mickiewicza w Poznaniu

ORCID: 0000-0002-3209-4932

e-mail: monikamm@amu.edu.pl

\section{LUKRECJA - WZÓR DLA RZYMIANEK. HISTORIA NIEZBYT SŁODKA}

\begin{abstract}
Miazek-Męczyńska Monika, Lukrecja - wzór dla Rzymianek. Historia niezbyt słodka (Lucrece as a model for Roman women. The story that is not very sweet).

The article presents the story of Lucrece, legendary heroine and noble wife of Lucius Tarquinius Collatinus, whose suicide was presented many times in the ancient Roman and Renaissance literature by historiographers and poets. The author compares few versions of Lucrece's story focusing on her virtues (like castitas, obstinata pudicitia, decus muliebris) that became canonical features characterising the Roman matrona.
\end{abstract}

Keywords: Lucretia; Lucrece; virtus; Ovid; Fasti; rape; Wiliam Shakespeare

Pełna poświęcenia postawa kobiet, heroizm posunięty do autodestrukcji, prowadzący ku śmierci - nierzadko samobójczej, popełnianej dla obrony własnej czci i honoru rodu, którego częścią stały się przez małżeństwo, są związane z rzymską mentalnością od zarania państwa. Wszak u początków republiki rzymskiej jako jej kamień węgielny leży dobrowolna ofiara Lukrecji ${ }^{1}$. Była ona córką rzymskiego patrycjusza Spuriusza Lukrecjusza Tricipitina i żoną Lucjusza Tarkwiniusza Kollatyna, bratanka króla Tarkwiniusza Pysznego. Pod nieobecność męża została sterroryzowana i zgwałcona przez królewskiego syna, Sekstusa Tarkwiniusza. Nie mogąc znieść hańby, wymogła na mężu przysięgę pomsty i popełniła samobójstwo - zadała sobie własnoręcznie cios sztyletem. Efektem tego samobójstwa było obalenie władzy królewskiej przez Lucjusza Juniusza Brutusa, świadka śmierci Lukrecji, jej mściciela i pierwszego konsula

\footnotetext{
${ }^{1}$ Michel Grant (1978: 199-200) zauważa, że historia Lukrecji „nosi piętno dobrze znanej tradycji: upadek tyranów przypisuje się znieważeniu siostry lub żony, którą trzeba pomścić”. Ten wątek o zabarwieniu mitycznym przeniknął być może na grunt rzymski z tradycji greckiej. Moment powstania opowieści pozostaje dla nas nieuchwytny, choć można przypuszczać, że była ona tematem ludowych pieśni czy romansów, a swoją popularność zawdzięczała rodowi Lukrecjuszów.
} 
republiki rzymskiej (wespół z mężem Lukrecji)². Według historyków wydarzenia te miały nastąpić w 509 r. p.n.e. Można więc poetycko stwierdzić, że republika rzymska wyrosła z krwi wypływającej z przebitego boku Lukrecji.

Jakkolwiek mamy tu do czynienia $\mathrm{z}$ legendą o trudno uchwytnym momencie powstania, jednak jej dramatyzm, dynamika zdarzeń, zaskakujący i monumentalny finał, wykorzystany dla uzasadnienia następstwa zdarzeń udokumentowanych historycznie, sprawiły, że powracała w sztuce łacińskiej i szerzej - europejskiej - na przestrzeni wieków w różnych odsłonach (prozatorskich, poetyckich, dramatycznych, a także malarskich) ${ }^{3}$, zaś ich autorzy, rozkładając akcenty w coraz to innych miejscach opowieści, wydobywali z niej nowe półtony.

Przyglądając się szczegółowo losom Lukrecji, należy pamiętać, że w żadnej mierze nie przyczyniła się ona do zaistnienia nieszczęśliwego splotu wydarzeń. Punktem wyjścia całej tragedii był bowiem spór toczony przez szlachetnie urodzonych młodych Rzymian przebywających w obozie wojskowym pod miastem Ardea ${ }^{4}$, którzy znudzeni przedłużającym się oblężeniem, skracali sobie czas ucztując. W trakcie jednej z uczt wywiązała się dyskusja, czy pozostawione w Rzymie żony są wierne swym mężom i która z nich najbardziej zasługuje na pochwałę. Gdy wzajemne przechwałki rozochoconych winem młodzieńców prowadziły już ku nieuchronnej kłótni, zapadła decyzja, by osobiście sprawdzić, co porabiają kobiety pod nieobecność mężów. Propozycję, by natychmiast wyruszyć do Rzymu, rzucił sam Kollatynus, przekonany o przewadze ukochanej Lukrecji nad wszystkimi rywalkami, nieświadomy jednak, że w ten

\footnotetext{
${ }^{2}$ Niestety dla Lucjusza Tarkwiniusza Kollatyna jego koneksje rodzinne z królewskim rodem okazały się zgubne i wkrótce także on został przez lud rzymski skazany na wygnanie, zob. Beard 2018: 116.

${ }^{3} \mathrm{~W}$ niniejszym tekście przedstawione zostaną dwa antyczne opracowania tej opowieści autorstwa Liwiusza (Ab Urbe condita, 1, 57-59) i Owidiusza (Fasti, 2, 723-893). Z literatury epok późniejszych pokazane zostaną Lukrecja, żona Kollatyna Giovanniego Boccaccia (z księgi O stynnych kobietach, XLVII) oraz poemat Williama Szekspira pt. Lukrecja. Oprócz wersji prozatorskiej i poetyckiej legenda o Lukrecji i upadku rządów królewskich w Rzymie doczekała się w starożytności opracowania dramatycznego, była bowiem tematem niezachowanej tragedii Lucjusza Akcjusza pt. Lukrecja. Wcześniej już Fabiusz Piktor wspominał o koligacjach rodzinnych Lucjusza Tarkwiniusza Kollatyna, a z zachowanych fragmentów Annales (fragmenty 251-252) Eniusza można wnioskować, że on również przywołał historię Lukrecji. Obszerny passus poświęcony jej losom znajduje się także w Bibliotece historycznej Diodora Sycylijskiego (X, 20, 1-21, 5). Zestawienie i omówienie opracowań oraz przedstawiań historii Lukrecji od antyku po epokę nowożytną sporządził Arthur Milton Young (Young 1964: 59-126). W sztuce postać Lukrecji stała się bardzo popularna zwłaszcza pod koniec XVI i w XVII wieku. Motyw gwałtu dokonanego na niej opracowali liczni malarze europejscy m.in. Lucas Cranach Starszy (kilka wersji), Rembrandt, Artemisia Gentileschi, Tycjan, Guido Reni, Parmigiano, Andrea Casali. Już w XX w. doczekała się także realizacji operowej - w 1946 r. Benjamin Britten stworzył operę w dwóch aktach pt. The Rape of Lucretia (Op. 37), z librettem Ronalda Duncana.

${ }^{4}$ Ardea była miastem zamieszkanym przez plemię Rutulów, z którymi Rzymianie toczyli w tym czasie wojnę.
} 
sposób przypieczętuje jej tragiczny los. Gdy mężczyźni zakradali się kolejno do własnych domów, ujrzeli swoje żony przy uczcie i zabawach, korzystające ze swobody. A co robiła Lukrecja?

Ona przędła: przy łożu kosz stał z miękką wełną.

Przy kaganku służące snuły gładką przędzę,

wśród nich pani mówiła swym łagodnym głosem:

„O, spieszcie się dziewczęta, trzeba jak najprędzej

panu płaszcz wysłać naszą ręką zgotowany [...]”.

(Fasti, II, 783-787)

Wielka była radość i duma Kollatyna, obserwującego żonę z ukrycia, a wszyscy uczestnicy wyprawy jednogłośnie przyznali Lukrecji zwycięstwo.

Owidiusz w swoim kalendarzu Fasti ${ }^{5}$ pozostawił poetycką wersję tych i następujących później wydarzeń, przejmując ich główny wątek od historyka Tytusa Liwiusza, który opisał historię Lukrecji w Dziejach Rzymu od założenia Miasta (Ab Urbe condita libri $C X X X X I I)^{6}$. Nade wszystko Owidiusz ukazał w swoich wierszach całą gamę uczuć Lukrecji. Gdy oglądamy ją po raz pierwszy - niejako z ukrycia, podpatrując ją wraz z Kollatynem i innymi uczestnikami zakładu, widzimy przede wszystkim jej pełen troski niepokój o przebywającego na wojnie męża, przemieszany z dumą z jego wojennych przewag. Lukrecja mówi do swoich służących, krzątających się wśród przędzy:

\section{[...] mój mąż jest bitny \\ i pewnie z gołym mieczem rzuca się na wroga. \\ Myśl ucieka, umieram, ilekroć go widzę \\ w wyobraźni, jak walczy; mróz przenika serce". \\ Urwała łkając, motek wypuściła z dłoni, \\ a twarz skryła w ramionach, jej gest był szlachetny, \\ szlachetne łzy wstydliwe, twarz zaś godna duszy.}

(Fasti, II, 792-798)

Gdy po chwili na dźwięk słów: „Rzuć lęki, już wróciłem!” Lukrecja padnie w ramiona męża i zawiśnie na jego szyi, powrócą siły życiowe, które odbierał jej niepokój o męża, jakby to właśnie od bliskości Kollatyna zależało nie tylko jej szczęście, ale wręcz - fizyczne trwanie. Owidiusz podkreśla bliskość i wzajemną serdeczność małżonków. $Z$ ich słów oraz gestów, tak oszczędnie przecież opisanych w obu relacjach, przebija miłość, troskliwość, duma. W tę

\footnotetext{
${ }^{5}$ Wszystkie cytaty z Fasti Owidiusza podaję w przekładzie Elżbiety Wesołowskiej za wydaniem: Owidiusz, Fasti. Kalendarz poetycki... W cytatach numeracja wersów zgodna z językiem wydania.

${ }^{6}$ Wszystkie cytaty z Ab Urbe condita Liwiusza podaję w przekładzie Andrzeja Kościółka za wydaniem: Liwiusz (Titus Livius), Dzieje Rzymu od założenia miasta. Księgi I-V...
} 
paletę pozytywnych uczuć wkrótce jednak wkrada się paraliżujący strach, przenikający Lukrecję owego feralnego wieczoru, gdy Sekstus Tarkwiniusz, przyjęty serdecznie jako krewniak, pogwałcił wszelkie prawa gościnności i wymusił na niej fizyczne oddanie ${ }^{7}$. Żona Kollatyna nie chciała się ugiąć nawet pod groźbą miecza, gotowa raczej stracić życie niż honor. Jednak przebiegły gwałciciel właśnie w tym umiłowaniu honoru znalazł swojego sprzymierzeńca. Nie mogąc wymóc posłuszeństwa prośbą ani przekupstwem, zagroził:

Próżny twój opór, w hańbie cię życia pozbawię: ja, gwałciciel, zaświadczę o twym cudzołóstwie fałszywie, sługę bowiem zabiję i powiem, że złapałem was razem.

(Fasti, II, 846-849)

Wobec takiego argumentu Lukrecja nie mogła już dłużej stawiać oporu.

Gdy następnego ranka gwałciciel odjechał, pohańbiona kobieta wezwała swojego męża i ojca wraz ze świadkami, by przedstawić wydarzenia ostatniej nocy. Relacje Liwiusza i Owidiusza różnią się w tej części znacząco. W Ab Urbe condita zapłakana, ale jednak spokojna Lukrecja opowiada wprost w krótkich zdaniach o krzywdzie, której doznała. Przy czym własny wstyd przenosi w znacznym stopniu także na męża, gdy wyznaniem: „Ślady obcego mężczyzny są w twoim łożu, Kollatynie" rozciąga zasięg hańby na swego ukochanego. Ohydny czyn królewskiego syna nie tylko zbrukał cześć Lukrecji, ale także splamił honor Kollatyna, a tym samym - całego jego rodu'. Pod-

${ }^{7} \mathrm{Na}$ temat rozterek Tarkwiniusza u wrót sypialni Lukrecji, przypisanych mu przez Williama Szekspira w poemacie Lukrecja, zob. Miazek-Męczyńska 2019: 97-100.

${ }^{8}$ Diodor Sycylijski przekazuje, że oprócz straszenia oskarżeniami o schwytaniu na cudzołóstwie, Tarkwiniusz próbował zyskać posłuszeństwo Lukrecji zapewnieniami o szczodrej nagrodzie: „Mądrzej więc postąpi, mówił, jeśli podda się jego żądzy nie wołając pomocy, a w nagrodę za tę łaskę otrzyma wielkie dary, będzie jego żoną i zostanie królową, zamieniając ognisko domowe prywatnego obywatela na pierwsze miejsce w państwie", cyt. za Grant 1978: 197. Św. Augustyn, odnosząc się do ostatecznego przyzwolenia (wymuszonego przecież siłą i groźbą!) Lukrecji na działania Tarkwiniusza, zastanawia się, czy w tym przypadku można mówić o gwałcie. Rozważając okoliczności jej samobójstwa, dopatruje się w nim wymierzonej własnoręcznie kary za to właśnie przyzwolenie, gdyż w innym wypadku samobójstwo Lukrecji nie miałoby żadnego uzasadnienia: „Puduit enim eam turpitudinis alianae in se commissae, etiamsi non secum, et Romana mulier, laudis avida nimium, verita est ne putaretur, quod violenter est passa cum viveret, libenter passa si viveret. Unde ad oculos hominum testem mentis suae illam poenam adhibendam putavit, quibus conscientiam demonstrare non potuit" (św. Augustyn, De Civitate Dei, 1. 19).

${ }^{9}$ William Szekspir rozwija ten wątek, wkładając w usta Tarkwiniusza słowa, które w uszach żony Kollatyna musiały brzmieć jak najstraszniejszy wyrok: „Tak po cześć twoją wraz z twym życiem sięgnę; [...] Mąż twój żyć dłużej będzie, lecz się stanie / Ofiarą drwiny wszystkich ust plugawej, / Ród głowę zwiesi, zhańbiony zostanie, / Dzieci w bękarty zmienią się nieprawe; / 
kreślając ten fakt, jak również przywołując poszarganie świętych dla Rzymian więzów gościnności (wszak „Hospes hospiti sacer”) przez Tarkwiniusza, który „z gościa stał się wrogiem”, Lukrecja przygotowuje emocjonalny grunt pod żądanie, jakie za chwilę wysunie wobec zgromadzonych, bliskich sobie mężczyzn. Oto pełna patosu domaga się od nich przysięgi, że cudzołóżca nie ujdzie bezkarnie. Na wszelkie próby pocieszenia odpowiada zaś stanowczo i... sentencjonalnie: „Wy myślcie tylko [...] co się jemu należy. Ja, choć się do winy nie poczuwam, nie zwalniam się od kary: nie będzie bezwstydnicy, która by żyła powołując się na przykład Lukrecji” (Ab Urbe condita, 1, 58). Te ostatnie słowa, wypowiedziane na chwilę przed ciosem sztyletu, Liwiusz przekazuje jako wyraźne przesłanie dla Rzymianek wszystkich następnych pokoleń. Odwracając zawartą w nim trzykrotną negację (,nec ulla deinde impudica Lucretiae exemplo vivet"), należy bowiem uznać, że skoro żadna bezwstydna niewiasta nie ma prawa powoływać się na przykład Lukrecji, to każda cnotliwa kobieta ma żyć (a w razie konieczności także umierać) właśnie według jej wzoru. Płacząca, ale dumna, znieważona, ale pełna godności Lukrecja miała być odtąd dla Rzymianek punktem odniesienia w obliczu rodzinnych i dziejowych tragedii.

Jakże inaczej zachowuje się Lukrecja w relacji Owidiusza. Zrozpaczona niczym „matka koło stosu syna” (Fasti II, 854), pogrążona w żałobie, zawstydzona, zapłakana, kiedy musiała opowiedzieć mężowi i ojcu o doznanej krzywdzie, trzykroć nie była w stanie wygłosić choćby słowa. Dopiero za czwartym razem zdobyła się na wyznanie, ale i wtedy przemilczała najbardziej drastyczne szczegóły, za dodatkową hańbę poczytując to, że sama musi wyznać swe nieszczęście. Lukrecja w Fasti nie wygłasza żadnych przemów, nie oczekuje pomsty, nie żąda dla siebie już niczego. W jej ostatnich słowach w wersji Owidiuszowej: „quam [...] veniam vos datis, ipsa nego” („Waszego przebaczenia sobie nie udzielam!", Fasti, II, 830) jest tyleż poczucia własnej godności, co rozpaczy. Choć mąż i ojciec zapewniają, że nie obarczają Lukrecji żadną winą, ona nie potrafi się ukoić. Własne ciało, jak nieustające memento, nie pozwala jej zapomnieć wydarzeń tamtej strasznej nocy i dlatego by odzyskać spokój ducha, Lukrecja musi się od ciała uwolnić - sięga po sztylet. Kobieca skromność, choć okrutnie zbrukana przez Tarkwiniusza, była do ostatniej chwili niezwykle ważna dla tej prawdziwie czystej dziewczyny, bo nawet gdy zalana krwią upadła do stóp ojca, „dbała, by przystojnie / upaść, bo taka była jej ostatnia troska” (Fasti, II, 874-875).

O tobie, która im wniosłaś niesławę, / I o twej zdradzie lud wierszyki skleci, / By je śpiewały po wiek wieków dzieci. [...] Broniąc małżonka i swych dzieci sprawy, / Ulegnij, nie chciej zostawić im w spadku / Niemijającej przenigdy niesławy, / Wstydu, co będzie w potomnych miał świadków” (w. 517, 519-525, 533-536). Poemat Szekspira powstał w 1594 r. i został zadedykowany Henrykowi Wriothesleyowi, hrabiemu Southampton. Wszystkie cytaty z Lukrecji Williama Szekspira podaję w tłumaczeniu Macieja Słomczyńskiego za wydaniem: Szekspir, Lukrecja ... 2004. 
Wyraźnie powraca w Owidiuszowym opisie Lukrecji wyznaczony przez Liwiusza kanon kobiecych cnót, których uosobieniem stała się żona Kollatyna: castitas, obstinata pudicitia ${ }^{10}$, decus muliebris (czystość, nieugięta skromność, kobieca cześć $)^{11}$. W każdej chwili, w każdej scenie Lukrecja jawi się czytelnikowi jako żona idealna, zdefiniowana jako taka już gdy po raz pierwszy obserwujemy ją oczami zakradających się Kollatyna, Tarkwiniusza i ich towarzyszy, pragnących podpatrzyć, czym zajmuje się pod nieobecność męża. „Ona przędła" - mówi krótko Owidiusz, zawierając w tych słowach najwyższą pochwałę, jaką mogła otrzymać rzymska matrona, pojawiającą się wszak nawet na nagrobkach, wśród takich cnót jak pobożność (pietas) oraz czystość $(\text { castitas })^{12}$.

W tradycji greckiej umiejętności tkackie jako przynależne wiernej, oddanej żonie łączą się nierozerwalnie z postacią Penelopy - to ona zwodziła natrętnych zalotników obietnicą, że podejmie decyzję o wyborze jednego z nich na męża, gdy skończy tkać całun dla swego teścia Laertesa. W stosownym fragmencie Homerowej Odysei (IX, 138-155) znajdujemy opis planu Penelopy, przedstawiony ustami jednego z konkurentów do jej ręki:

Oto jaki podstęp uknuła w swym łonie: ustawiła w pokoju krosna i zaczęła tkać na nich wielką delikatną tkaninę, a nam powiada: „Chłopcy zalotnicy, umarł boski Odys, ale choć tak wam śpieszno do ślubu, pozwólcie najpierw skończyć tę szatę, by mi się przędza nie zmarnowała; ma to być giezło grobowe dla herosa Laertesa, gdyby go kiedyś dola okrutna powaliła drętwą śmiercią [...]". Tak mówiła i usłuchało męskie serce. Odtąd za dnia tka na wielkich krosnach, a w nocy pruje przy łuczywie. Przez trzy lata się z tym ukrywała i zwodziła Achajów. Lecz gdy nadszedł czwarty rok a z nim wiosna, wygadała się któraś z kobiet, znająca tajemnicę. Zaskoczyliśmy ją, jak pruła piękną tkaninę i musiała dokończyć wbrew woli. (przeł. J. Parandowski)

\footnotetext{
${ }^{10} \mathrm{Na}$ temat zinstytucjonalizowanego kultu pudicitiae jako bogini zob. Langlands 2006: 3777; Mikocki 1997: 197-265.

${ }^{11}$ Gwoli prawdy trzeba przyznać, że nie wszyscy Rzymianie oczekiwali od swoich żon skromności - przynajmniej nie w sypialni. Satyryk Marcjalis, którego epigramaty przynoszą znacznie mniej posągowy obraz rzymskiej obyczajowości I wieku n.e., w jednym z utworów wyraźnie podkreśla, że jego żona może za dnia naśladować Lukrecję, jeśli taką ma chęć, on jednak wolałby, żeby nocą była podobna do kurtyzany Lais: „Si te delectat gravitas, Lucretia toto / sis licet usque die: Laida nocte volo". (Martialis, Epigram. 11. 104, w. 21-22). Marcjalis przywołuje miano Lukrecji jeszcze parokrotnie (cf. Langlands 2006: 83), używając jej imienia jako swego rodzaju maski, za którą skrywają się kobiety na pozór tylko skromne i przyzwoite - gdy jakiś „Brutus” może je obserwować, ale w rzeczywistości rozpustne i siejące zgorszenie, a nawet czytujące wiersze samego Marcjalisa („Erubuit posuitque meum Lucretia librum, / sed coram Bruto; Brute, recede: leget", Epigram. 1.16, w. 9-10).

${ }^{12}$ Jako utrwalone tradycją należy uznać pojawiające się na nagrobkach następujące określenia kobiet: „optima, pulcherrima, lanifica, pia, pudica, casta, domiseda”, cf. CIL (Corpus Inscriptionum Latinarum) 6.11602; epigram 223 w Carmina Latina Epigraphica, colligit E. Engström, GotoburgiLipsiae 1902. Szerzej na ten temat zob. Casamayor Mancisidor 2015; Krawczyk 2013.
} 
W ten sposób postać Penelopy została na zawsze złączona z krosnami i przędzą $^{13}$, wynalazkami dziewiczej bogini Ateny ${ }^{14}$, skądinąd opiekunki jej męża Odyseusza. Natomiast w tradycji rzymskiej wzorzec matrony-prządki utrwaliła właśnie postać Lukrecji, a umiejętność przędzenia i tkania zaliczana była do podstawowych obowiązków (labor matronalis) rzymskiej szacownej mater familias ${ }^{15}$ w Rzymie epoki republikańskiej i augustowskiej. Sam Oktawian August, pragnąc wskrzesić dawne rzymskie obyczaje w ramach starań o odnowę moralną swoich współobywateli, polecił, by Rzymianki za szlachetnych rodów, w tym również kobiety z jego rodziny, wróciły do samodzielnego przędzenia i tkania materiałów. Jak przekazuje Swetoniusz, August miał nosić tylko ubrania wykonane własnoręcznie przez swoje krewne ${ }^{16}$.

Ukazanie Lukrecji pochylającej się nad przędzą, wykonującej prace tkackie, nacechowane tak silnymi skojarzeniami z dbałością o ognisko domowe, męża i rodzinę, a wreszcie lokujące kobietę we wnętrzu domu, czyli miejscu tradycyjnie jej przypisanym, pozwalało czytelnikowi już od pierwszego momentu uznać ją za ideał żony ${ }^{17}$. William Szekspir wykorzystał to utożsamienie kobiecych

\footnotetext{
${ }^{13}$ Krytyka feministyczna łączy tę sferę kobiecej aktywności w antyku z opresją, widząc w niej głównie zamknięcie kobiet w wewnętrznej strefie domu, oddzielenie od wszelkiej działalności zewnętrznej - przynależnej mężczyznom, wreszcie - ograniczenie dla motywacji intelektualnej czy fizycznej, wynikające z monotonnej powtarzalności prac tkackich. Dodatkowo podnoszonym argumentem, uwypuklającym aspekt opresyjny, jest częste powiązanie w tradycji antycznej postaci tkającej bądź przędącej kobiety z fizycznym gwałtem lub inną krzywdą, jakiej doświadcza bohaterka (np. Filomele, Arachna). Ewelina Krawczyk, w nieopublikowanej pracy Uwikłane. Tkanie i przędzenie a opresja kobiet $w$ literaturze starożytnej Grecji i Rzymu, używa dosadnego określenia: „w pewnym momencie prehistorii dokonała się zbrodnia założycielska: przykucie kobiet do kądzieli” (Krawczyk 2013: 7). Nie sposób jednak nie zauważyć również zupełnie innego, nieomal sakralnego wymiaru tkactwa w starożytności, skoro wedle wierzeń Greków i Rzymian nić ludzkiego życia spoczywała w rękach Mojr (Parek), odpowiedzialnych za snucie jej i przecięcie w chwili śmierci.

${ }^{14} \mathrm{~W}$ czasach Renesansu Giovanni Boccacio zasługę wynalezienia tkactwa przypisał natomiast pramatce Ewie, łącząc w sposób nierozerwalny kobiecość z umiejętnością produkcji materiałów, cf. Łukaszewicz-Chantry 2011: 160-161.

${ }^{15}$ Zob. np. Larsson Lovén 2013; Jundziłł 1986: 50; Korpanty 1980.

${ }^{16}$ Swetoniusz poczytuje to za jeszcze jeden dowód skromności i stronienia od zbytków, jakie miały cechować Augusta: „Mówią, że zawsze sypiał na łożu niskim i skromnie zasłanym. Szaty innej nie używał jak tylko domowej roboty, wykonanej rękoma siostry, żony, córki lub wnuczki. Togi nosił ani zbyt opięte, ani zbyt luźne, szlak purpurowy umiarkowanej szerokości [...].”, Gajusz Swetoniusz Trankwillus, Żywoty cezarów. Księga II: Boski August, 73.

${ }^{17}$ Wart podkreślenia jest fakt, że obraz Lukrecji zajmującej się robótkami ręcznymi nie cieszył się tak wielkim zainteresowaniem mistrzów palety jak scena gwałtu. Pozbawiony dynamiki oraz emocji, statyczny i wyciszony ze swej natury proces tkania, przędzenia czy haftowania, sprowadzający się zapewne dla wielu osób - zwłaszcza mężczyzn - do określenia „nudny”, nie wydawał się malarzom szczególnie interesujący. Niemniej został on uwieczniony przez Willema de Poorter na obrazie pt. Tarquinius Finding Lucretia at Work (1633), znajdującym się w zbiorach Musée des Augustins w Tuluzie [https://jhna.org/willem-de-poorter-tarquinius-finding-lucretia-at-work/], dostęp dnia: 01.07.2021.
} 
aktywności w sferze domowej z robótkami ręcznymi, by w swoim poemacie Lukrecja uczynić igłę ostatnią strażniczką sypialni Lukrecji. Gdy zawiodły już kolejne drzwi, gdy podmuchom wiatru nie udało się zgasić pochodni, którą Tarkwiniusz oświetlał sobie drogę do komnaty żony Kollatyna, a nawet cisnący się w oczy dym nie zatrzymał go w progu, w obronie swej pani wystąpiła skromna igła, wbita w porzuconą rękawiczkę:

[Tarkwiniusz] Podniósł ją z maty, na której spoczywa,

Gdy ścisną, igła go w palec zraniła;

„Nie znam swawoli” - czyniąc tak mówiła -

„Odejdź i porzuć drogi niegodziwe,

Ja i ma pani jesteśmy cnotliwe".

(Szekspir, Lukrecja, 317-322)

Ten skromny oręż, niezdolny ochronić Lukrecję przed gwałcicielem, byłjak się zdaje - jedynym ostrzem stosownym dla kobiet. Igła, stając w obronie swojej pani, podkreśla jej doskonałość jako rzymskiej matrony - czystej i oddanej pracom domowym. A wszystkie kolejne sceny, w jakich żona Kollatyna została pokazana aż po chwilę śmierci, tylko pogłębiają to przekonanie, czyniąc z niej wzorzec dla wszystkich Rzymianek ${ }^{18}$. Lukrecja w sposób mniej lub bardziej świadomy sama wchodziła w tę rolę, spełniając wszelkie oczekiwania społeczne. Będąc częścią swego rodu, postrzega własne nieszczęście w wymiarze rodzinnym. Swoje zgwałcone ciało traktuje jako nieczyste, niegodne kontaktów fizycznych z własnym mężem, ale przede wszystkim niegodne macierzyństwa ${ }^{19}$. Utrata (nawet niezawiniona) cnoty, niezbywalnej cechy rzymskiej matrony, odebrała Lukrecji wszelkie przywileje małżonki i pani domu, które odzyskać mogła jedynie zmywając hańbę własną krwią. Wolno urodzona Rzymianka musiała bowiem pozostać nieskazitelna, gdyż na jej czystości zbudowany był cały gmach porządku społecznego: prawowite potomstwo, rodzina, pozycja rodu, przynależność do stanu, wreszcie tożsamość rzymska ${ }^{20}$. Ciężar tej odpowiedzialności musiała odczuwać również Lukrecja.

\footnotetext{
${ }^{18}$ Podkreśla to zwłaszcza Diodor Sycylijski: „Niewiasta bowiem [tj. Lukrecja], która dobrowolnie wyrzekła się życia po to, aby przyszłe pokolenia miały wzór cnoty godnej naśladowania, zasługuje naszym zdaniem na nieśmiertelną chwałę, dzięki której kobiety strzegące swej czystości od wszelkiej skazy i nagany mogą swe postępowanie porównywać z prawdziwym ideałem", cyt. za Grant 1978: 197.

${ }^{19} \mathrm{Cf}$. Besala 2010: 195. Również Pierre Grimal (2005: 33) komentując determinację Lukrecji w dążeniu do śmierci, podkreśla, jak silnie gwałt wpływał na pozycję kobiety w rodzinie: „Owa bezkompromisowość [...] znajduje swoje wyjaśnienie w głębokim przekonaniu, że przewinienie tego rodzaju jest czymś materialnym, nieusuwalnym, co na zawsze oddala żonę od męża, czyniąc ją niegodną ponownego znalezienia się przy ognisku domowym".

${ }^{20} \mathrm{Cf}$. Besala 2010: 197.
} 
Liwiusz $^{21}$ i Cyceron ${ }^{22}$ zestawiają Lukrecję $\mathrm{z}$ inną na poły legendarną postacią - Werginią, plebejuszką zasztyletowaną przez własnego ojca Lucjusza Werginiusza, który chciał ocalić ją w ten sposób przed zhańbieniem przez Appiusza Klaudiusza, jednego ze sprawujących wówczas władzę decemwirów. Wydarzenia te spowodowały wybuch rewolty w mieście i drugą secesję plebejuszy, co doprowadziło do obalenia władzy decemwirów w 449 r. p.n.e., a w efekcie do pełnego uformowania ustroju republikańskiego Rzymu. Jak podaje Werner Riess, w obu przypadkach czystość i niewinność rzymskiej kobiety i nienaruszalność jej ciała były symbolami nienaruszalności samego Rzymu - Romy (podkreślmy tu zatracony w tłumaczeniu rodzaj żeński), a godne szacunku ciało kobiety stawało się symbolem państwa rzymskiego ${ }^{23}$. Dwakroć zadany kobietom gwałt - jako kropla przepełniająca czarę - przyczynił się do rewolt i wprowadzenia zmian ustrojowych w Rzymie ${ }^{24}$. W obu też przypadkach to mężowie lub krewni kobiety zyskali dzięki jej śmierci stanowiska i zaszczyty: mąż Lukrecji został konsulem, natomiast ojciec, narzeczony i być może również dziadek Werginii zostali wybrani trybunami ludowymi ${ }^{25}$. Obie sytuacje różni tylko jeden ważny szczegół - o ile Lukrecja dokonała świadomego wyboru i sama złożyła się w ofierze, to Werginia stała się ofiarą z woli swojego ojca - przynajmniej o ile możemy wnioskować z zachowanych źródeł literackich ${ }^{26}$. Dodać należy,

${ }^{21}$ Zob. Ab Urbe condita 3, 44-58.

${ }^{22}$ Zob. De re publica 2, 63; De finibus bonorum 2, 66; 5, 64.

${ }^{23}$ „In both cases, the chastity and purity of a Roman woman as well as her sexual inviolabity symbolized the invulnerability of Rome itself. The honorable female body stood for the Roman body politic as a whole. [...] The mythological violence inflicted on Lucretia and Verginia can be understood as foundational violence, according to Rene Girard. Lucretia's suicide triggered the fall of the Tarquins and thus accelerated the dawn of the Roman Republic. The death of Verginia ended the tyrannical decemvirate and led to a new Concordia between patricians and plebeians during the struggle of the orders. Lucretia and Verginia thus became foundational figures, guiding parameters for ideal female conduct in the Roman imagination as expressed in Roman mythology and moralistic historiography" (Riess 2012: 492).

${ }^{24}$ Komentując te zdarzenia, Pierre Grimmal (2005: 33) pisze: „Nie mówmy, że sprawa Lukrecji była tylko przypadkową przyczyną wygnania króla. W gruncie rzeczy Rzymianie byli przekonani, że zbrodniczy czyn Tarkwiniusza jest nieuniknionym skutkiem istnienia monarchii. Wydawało się czymś nieuchronnym, że ustrój, składający absolutną władzę w ręce jednostki, musi w niej, a zarazem we wszystkich dzielących jej przywileje, zrodzić pogardę dla tego, co najświętsze: miłości do żony, szacunku dla samego siebie, nietykalności domowego ogniska. Rządy królewskie, wyradzając się w tyranię, musiały doprowadzić do gwałtów, u których podłoża leżała irracjonalna namiętność - przekleństwo zsyłane przez niebian na winnych grzechu bezbożności".

${ }^{25}$ Cf. Joshel: $115-117$.

${ }^{26}$ Scena śmierci Werginii została przez Liwiusza sportretowana następująco: „Wtedy Werginiusz, nie widząc znikąd pomocy [...] odprowadził córkę i piastunkę na bok ku świątyni Kloacyny koło kramów, które teraz nazywają się Nowymi, i tam porwawszy od rzeźnika nóż rzekł: «W ten tylko jedyny sposób, córko, mogę dać ci wolność!». Tu przebił pierś dziewczyny, a odwróciwszy się do trybunału rzekł: «Na ciebie i na twoją głowę, Appiuszu, niech spadnie ta krew!»", Ab Urbe condita 3,48 . 
że powtarzalność owego schematu, widoczna w obu narracjach, dowodzi ich silnego sfabularyzowania i przesuwa je w sferę legendy, a nie historii. Co nie przeszkadzało jednak Rzymianom traktować tych wydarzeń jako realne.

Abstrahując jednak od wymiaru politycznego powyższych opowieści, warto skoncentrować się na bardziej prywatnym aspekcie samobójczej śmierci Lukrecji - na kwestii honoru i męstwa, czyli łacińskiej cnoty virtus ${ }^{27}$. Nieprzypadkowo pobrzmiewa w tym słowie (podobnie jak w jego polskim odpowiedniku) pokrewieństwo z rzeczownikiem vir - mężczyzna, mąż ${ }^{28}$. Wybierając śmierć zamiast życia z poczuciem hańby, Lukrecja po raz pierwszy zachowuje się ,niekobieco". Wszystkie jej wcześniejsze działania (spędzanie czasu na przędzeniu, gościnność wobec przybysza, a nawet wyłącznie bierny opór stawiany Tarkwiniuszowi) wpisywały się w kanon ogólnych zachowań, jakich od swoich córek i żon oczekiwali Rzymianie. Wśród toczących się wokół niej wydarzeń - spowodowanych przez mężczyzn zgodnie z ich pragnieniami - ona pozostaje właściwie bierna. Jest niczym pionek ustawiany na odpowiednich polach planszy przez graczy. Dopiero sięgnięcie po sztylet staje się aktem odrzucenia zachowań przypisanych kobiecie przez męskie otoczenie. I ojciec, i mąż Lukrecji są, jak się zdaje, przekonani, iż najbardziej dręczy ją poczucie winy, że sama doprowadziła w jakimś stopniu do gwałtu (czyż w innym przypadku przekonywaliby ją, ,że winę ponosi sprawca zbrodni, a nie ona zgwałcona"?) i że oczekuje od nich usprawiedliwienia, czy też wybaczenia. Tymczasem Lukrecja odrzuca ich pocieszenie, bo sama siebie nie jest w stanie pocieszyć, sama sobie nie potrafi wybaczyć. Czego? Czy faktu, że została ofiarą przemocy, czy może tego, że nie umiała się przed nią obronić, czy wręcz tego, że nie jest w stanie sama dokonać pomsty za upokorzenie i hańbę - nie tylko własną, ale również swojego męża i całego rodu? Może wszystkiego po trosze. Jedyną formą zemsty, jakiej jako kobieta może dokonać, jest dla Lukrecji samobójstwo. Tylko w tej kwestii może

${ }^{27}$ W Stowniku łacińsko-polskim pod redakcją Mariana Plezi (Warszawa 1999, vol. V, s. 629, s.v. virtus) jako pierwsze znaczenie słowa virtus figuruje męstwo, dzielność, bohaterstwo [...] zwt. w boju.

${ }^{28}$ Taką interpretację przyjął już Cyceron, uznając virtus za cnotę przynależną mężczyznom: „apellata est enim ex viro virtus” (Cicero, Disputationes Tusulanae 2, 43). Wymienia ją także jako drugą z cnót przynależnych dobrym wodzom, obok znajomości spraw wojskowych, autorytetu i szczęścia (,ego enim sic existimo, in summo imperatore quattuor has res inesse oportere, scientiam rei militaris, virtutem, auctoritatem, felicitatem", Cicero, De imperio Gnaei Pompeii 28). W interesujący sposób ścisłe połączenie pojęć vir i virtus uzasadnia Thomas E. Strunk (2014: 137), opisując funkcjonowanie tych pojęć u Liwiusza w kontekście porwania Sabinek: „Romulus solicits Rome's neighboring towns seeking marriage alliances for his citizens, emphasizing the Romans' virtus, but finding them uncooperative, Romulus turns to force [...] the rape of the Sabine women fulfills a number of functions, namely women were introduced to Roman society, but equally important the abduction of the Sabine women demonstrated the courage and manliness of the Romans, who were denied by communities unwilling to recognize them as legitimate partners. Once the Romans have taken the Sabine women, they are designated for the first time by Livy as viri". 
też dokonać wyboru - rozstrzygnąć o być albo nie być swojego ciała, którym dotąd rozporządzali mężczyźni. W ten sposób wkracza niejako w męskie kompetencje, poszerzając wachlarz swych rozlicznych cnót niewieścich o tak bardzo męską cnotę jak virtus.

Można uznać, że tak jak swoim życiem ustaliła Lukrecja ideał rzymskiej matrony, tak swoją śmiercią wyznaczyła wzorzec mężnej kobiety. Mianem „animi matrona virilis” („niewiasta o męskiej duszy”) określa ją Owidiusz w Fasti $(\text { II, 847 })^{29}$. To właśnie postać Lukrecji wdrukowała w powszechną świadomość model kobiety mężnej w znaczeniu moralnym, stając się godnym bezwarunkowego naśladowania wzorem dla kolejnych pokoleń Rzymianek ${ }^{30}$, które w skrajnie trudnych sytuacjach jedyną drogę do ocalenia czci własnej, swojego męża i rodu, upatrywały odtąd w samobójstwie, stawiając honor rodziny ponad własne życie.

Co ciekawe, swoisty kult Lukrecji pielęgnowany w epoce republikańskiej i w czasach cesarstwa, odrodził się wśród mieszkanek Italii po latach wraz nastaniem Renesansu. Odrodzeniowe Włochy ożywiły mit Lukrecji zarówno w sztuce wysokiej, jak też użytkowej. Postać rzymskiej heroiny pojawiała się wielokrotnie na obrazach wielkich mistrzów. Sam Dante odnotował jej obecność w Piekle ${ }^{31}$ wśród znakomitości starożytnego świata, czyli ludzi szlachetnych, którzy żyjąc przed narodzeniem Chrystusa nie mieli możliwości poznać wiary chrześcijańskiej i tym samym - dostąpić zbawienia. Petrarka umieścił ją wśród bohaterek starożytnych postępujących w orszaku Czystości w Triumphus Pudicitiae $^{32}$, a dłuższą uwagę poświęcił Lukrecji w poemacie epickim Afryka (ks. III, w. 684-802), opisując głównie jej boleść i narastającą nienawiść do własnego ciała, które stało się przyczyną wstydu. Jako wzór do naśladowania dla swoich trzech córek wskazywał ją Giovanni Pontano w elegii Ad uxorem de

${ }^{29} \mathrm{~W}$ literaturze antycznej co prawda nie pojawia się w odniesieniu do Lukrecji termin virago, jak określano kobietę obdarzoną męskim charakterem, ale wydaje się, że do postawy Lukrecji w obliczu śmierci bardzo dobrze pasuje definicja, którą Serwiusz zawarł w komentarzu do Ene$i d y$ : „Virago dicitur mulier, quae virile implet officium, id est mulier, quae viri animum habet: has antiqui viras dicebant" (Serv. In Aen. XII 468).

${ }^{30} \mathrm{Cf}$. Shelton 2013: 35-37.

${ }^{31}$ Lukrecja znajduje się tam $\mathrm{w}$ doborowym gronie bohaterów epoki antycznej, zarówno kobiet, jak i mężczyzn: „Śród traw zielonych, jako za epoką, / szlachetne cienie mi się ukazały, / od których w sercu jeszcze mi szeroko. / Była Elektra i jej orszak cały: / Hektor, Eneasz dzielni wojownicy, / był z okiem sępa w zbroi Cezar śmiały, / Pentezylei cień, Kamy - dziewicy, był z innej strony cień króla Latyna, / co miał Lawinię po swojej prawicy. / Był Brutus, który przepędził Tarkwina, / Lukrecja, Julia, Marcja, Grakchów matka” (Dante, Boska Komedia, Piekło, pieśń IV, w. 118-128). Po raz drugi Lukrecja została wspomniana przez Dantego (również w kontekście Tarkwiniuszowego gwałtu) w Raju (pieśń VI, w. 41).

${ }^{32}$ Jest to druga część nieukończonego poematu alegorycznego Petrarki pt. Triumfy (Triumphi), ukazującego kolejne zwycięstwa alegorycznych postaci: Miłości, Czystości, Śmierci, Sławy, Czasu i Wieczności, a więc sił władających ludzkim istnieniem. Obok Lukrecji w tryumfie Czystości (Pudicitia) uczestniczą Penelopa i Dydona. 
liberis educandis ${ }^{33}$. Motyw Lukrecji chętnie umieszczany był także na skrzyniach posagowych, przekazując symbolicznie, że oto panna młoda wnosi małżonkowi w wianie cnotliwość i wierność ${ }^{34}$.

Tymi właśnie przymiotami scharakteryzował Lukrecję również Giovanni Boccaccio, w pierwszych słowach jej biogramu zamieszczonego w zbiorze pt. O stynnych kobietach: „Lukrecja, nadzwyczajny wzór rzymskiej obyczajności i godny czci przykład niegdysiejszej skromności" ${ }^{35}$. Boccaccio, powielając w zasadzie narrację Liwiusza, włącznie z zacytowaniem przedśmiertnych słów bohaterki, zamyka opowieść odautorskim komentarzem:

Doprawdy nieszczęsna była uroda Lukrecji. Jednak cnota jej (nigdy nie dosyć wychwalana) zasługuje na tym większą pochwałę, z im większą determinacją kobieta zmazała hańbę gwałtu. Czyn Lukrecji nie tylko przywrócił jej dobre imię odebrane przez haniebny postępek lubieżnego młodzieńca, lecz także obdarzył Rzym wolnością.

Boccacio wyraźnie podkreśla, że dla Lukrecji obrona swojego dobrego imienia stanowiła wartość nadrzędną. Uwypukla to również w opisie sceny gwałtu, gdy stawiająca opór napastnikowi wierna żona zamiera, słysząc groźbę pośmiertnej niesławy. Wizja oskarżenia o cudzołóstwo z niewolnikiem, czego martwa nie mogłaby się wyprzeć, zmusza ją do rezygnacji z walki. Ze wzgardą w duszy oddaje Tarkwiniuszowi swoje ciało. Wybiera mniejsze zło i zgadza się doznać hańby za życia, by uniknąć hańby po śmierci, świadoma, „że - jeśli zginie w ten sposób - nie znajdzie się nikt, kto przywróci jej dobre imię". Poddana męskiej opresji, przez całe życie tak silnie uzależniona od mężczyzn, Lukrecja podejmuje w tym momencie bardzo samodzielną i w pełni świadomą decyzję - być może pierwszą tak całkowicie indywidualną. Od tego momentu działa w sposób przemyślany i konsekwentny: wraz z nastaniem dnia wzywa swoich krewnych, ukrywa sztylet $\mathrm{w}$ fałdach szaty, przedstawia mężczyznom przebieg wydarzeń, a po uzyskaniu obietnicy pomsty - odbiera sobie życie. Choć opowieść o gwałcie przeplata strumieniami łez (co można odczytać przede wszystkim jako wyraz wstydu i zażenowania $^{36}$, a nie kobiecej słabości), nic nie jest w stanie zmienić jej decyzji. W pewnym stopniu Lukrecja zrzuca wręcz z siebie władzę ojca i męża, dokonując samodzielnego wyboru i okazując nieposłuszeństwo, gdy starali się

${ }^{33}$ Cf. Łukaszewicz-Chantry 2014: 42-44.

${ }^{34}$ „Ta rzymska heroina traktowana była niemal jak chrześcijańska święta”, podkreśliła dr Grażyna Bastek, historyk sztuki, w Programie Drugim Polskiego Radia w audycji pt. Każda mężatka chciała być jak Lukrecja z cyklu Jest taki obraz (data emisji: 18.01.2015). Omawiano tu obraz Lorenza Lotta pt. Portret kobiety inspirowany postacia Lukrecji [http://www.polskieradio.pl/8/406/ Artykul/1355708,Kazda-mezatka-chciala-byc-jak-Lukrecja, dostęp: 01.07.2021.]

${ }^{35}$ Fragmenty z biogramu Lukrecji autorstwa Boccaccia cytuję w przekładzie Piotra Bańkowskiego za wydaniem: Giovanni Boccaccio, O stynnych kobietach..., 276-281.

${ }^{36}$ Widać to doskonale w poetyckiej narracji Owidiusza, cf. Fasti, II, 864-868. 
ją uniewinnic ${ }^{37}$. To ona zadecyduje o własnym życiu i ciele, które gwałt popełniony przez Tarkwiniusza niejako jej odebrał. Swoją władzę nad własnym ciałem odzyskuje Lukrecja w akcie autodestrukcji.

Dla Boccaccia, podobnie jak dla Liwiusza, na którym włoski twórca wzorował swoją opowieść, dramatyczne zdarzenia w domu Kollatyna nabrały szczególnego sensu dzięki ich historycznym konsekwencjom. Nie pierwszy to raz w dziejach starożytnych kobieca piękność i męska żądza stały się przyczyną krwawych rozstrzygnięć i wpłynęły na losy państwa, by wspomnieć tylko królową Sparty Helenę i wojnę trojańską. Pamiętając, że Rzym na mocy boskich wyroków miał być nową Troją, można dopatrywać się daleko posuniętych analogii w obu historiach. I Parys, i Sekstus Tarkwiniusz byli królewskimi synami. Obaj zapragnęli posiąść cudze żony - piękne i szlachetnie urodzone. Obaj zostali przyjęci gościnnie pod nieobecność panów domu. Obaj pogwałcili tę gościnność w najbardziej nikczemny sposób. O ile jednak wedle najbardziej rozpowszechnionej wersji mitu Helena uległa Parysowi i odwzajemniła jego uczucia, ściągając w efekcie zagładę na Troję, to Lukrecja stawiła opór zalotnikowi, a swoją ofiarą zagwarantowała przyszłą wielkość Rzymowi - nowej Troi. Bunt ludu rzymskiego, wygnanie znienawidzonego króla, ustanowienie republiki wraz z urzędem konsula, „obdarzenie Rzymu wolnością” - jak podsumowuje Boccaccio - stanowiły w oczach pisarzy wartość nadrzędną i jeśli nie usprawiedliwiały, to przynajmniej nadawały szlachetny wymiar tej tragicznej opowieści. Nawet dla Owidiusza, operującego wszak zupełnie inną paletą emocji, naturalnym było powiązanie dziejów Lukrecji z historią polityczną Rzymu, skoro punktem wyjścia do ich przedstawienia w poetyckim kalendarzu Fasti stało się obchodzone rokrocznie święto Regifugium ${ }^{38}$, upamiętniające wygnanie Tarkwiniusza Pysznego i jego syna. Dopiero William Szekspir w swoim poemacie Lukrecja potraktował aspekt historyczno-polityczny jako całkowicie drugorzędny, zawierając go w zaledwie trzech ostatnich z liczącego 1953 wersy poematu:

Gdy się bezzwłocznie ta rzecz dokonała, Zgodę z radością dali im Rzymianie $\mathrm{Na}$ Tarkwiniusza wieczyste wygnanie. (Szekspir, Lukrecja, 1951-1953)

${ }^{37}$ Jak pisze Pierre Grimal (2005: 33): „Młoda kobieta, bohaterski wzór małżeńskiej wierności, nie chce słuchać ojca i męża, zupełnie słusznie usprawiedliwiających to, co nazywa swoją przewiną. Nie uznaje żadnych okoliczności łagodzących. Jej zbrukane ciało musi zostać unicestwione, a skażona krew rozlana, nawet jeśli dusza pozostała czysta”.

${ }^{38}$ Regifugium (dosł. „Ucieczka króla”) - zgodnie ze współczesną rachubą czasu, święto to miało miejsce 24 lutego. Wedle relacji Plutarcha (Questiones Romanae, 63) w tym dniu odgrywano scenę wypędzenia ostatniego władcy - wybrany Król Ofiarny opuszczał w pośpiechu Forum Romanum. Bliższe szczegóły rytuału nie są jednak znane. 
Nie oznacza to jednak, że u Szekspira nie ma mowy o władzy i polityce, tematach przeplatających się w niemal wszystkich utworach angielskiego dramaturga. Lukrecja okazuje się tu być osobą świadomą politycznie, w równym stopniu co Tarkwiniusz znającą mechanizmy władzy. Walcząc z napastnikiem na słowa, gdyż fizycznie nie może stawić mu wystarczającego oporu, dobiera argumenty z obszaru męskiej retoryki. Mówi o pozycji i roli króla, o szacunku należnym władcy budowanym przez niego każdym czynem i o druzgocących skutkach utraty tego szacunku. Jej słowa nie mają jednak żadnej mocy, ponieważ te same argumenty Tarkwiniusz już wcześniej rozważył i odrzucił, niezdolny do przeciwstawienia się mrocznemu pożądaniu. I przyznaje się do tego wprost:

\footnotetext{
Wiem, ile cierpień czyn ten w plonie zbierze,

Znam kolec, który przy róży waruje,

Dostrzegam żądło, które miodu strzeże,

Wszystko to naprzód mój umysł pojmuje,

Lecz głucha żądza rad nie uszanuje,

Jej okiem tylko na piękno spoglądam

I, choć wbrew prawom, szalejąc, pożądam.
}

(Szekspir, Lukrecja, 491-497)

Rozpamiętując wydarzenia minionej nocy, czekając na przybycie męża i ojca szekspirowska Lukrecja porównuje swoje losy do zdobytej podstępem Troi. Widzi w sobie odbicie króla Priama, który uwierzył zdradzieckiemu Sinonowi ${ }^{39}$ i pozwolił wprowadzić drewnianego konia w mury rodzinnego miasta - jego błędy zemszczą się na jego rodzinie i na całej poddanej mu społeczności. Ale postrzega się również jako Hekabe, rozpaczającą nad upadkiem swojego rodu. Wyjąca z bólu nad zwłokami bliskich, świadoma końca swojego świata żona Priama, niegdyś posągowa matka i wzorowa małżonka, teraz marzy tylko o śmierci. Podobnie czuje Lukrecja. I te uczucia pozwalają jej podjąć decyzję. Wkrótce opowie przybyłemu Kollatynowi zdarzenia minionej nocy, wyzna powody swej uległości, odbierze przysięgę pomsty i umrze, wypowiadając długo skrywane imię swojego gwałciciela. Nad płacz ojca i męża Lukrecji wzbije się jednak już chwilę później opanowany, choć nabrzmiały emocjami głos Brutusa, wzywający wszystkich obecnych do pomsty. A zakrwawione ciało kobiety, oczyszczone ze zmazy przez śmierć, posłuży jako dowód zbrodni, stając się symbolem ciemiężonego królestwa, gotowego do zrzucenia jarzma tyrańskiej władzy.

Czy takiego finału spodziewała się Lukrecja, wbijając w swoją pierś ostrze sztyletu? Z pewnością nie. Żyjąc w kręgu kobiecych prac domowych, wychowana w przynależnych jej stanowi skromności i pobożności, nie mogła nawet podejrzewać, że stanie się przyczyną przewrotu ustrojowego. Traumatyczne doświadczenie, którego nie umiała i nie chciała przemilczeć, wyprowadziło ją

\footnotetext{
${ }^{39}$ Zob. Wergiliusz, Eneida, ks. II, w. 195-199. Sinona można również znaleźć wśród zdrajców w dantejskim Piekle.
} 
jednak z domowego zacisza na forum. Własne ciało, odzyskane na chwilę w akcie samobójstwa, ponownie zostało zawłaszczone przez mężczyzn, obnażone, pokazane współobywatelom, wykorzystane do zaspokojenia kolejnych męskich ambicji. W ten sposób Lukrecja, wzór żony za życia, nawet po śmierci przyczyniła się do pomnożenia chwały swojego męża i rodu, a w efekcie - także ojczyzny. I może to jest jedyna słodka nuta w tej historii, skoro - jeśli wierzyć Horacemu - „Dulce et decorum est pro patria mori ${ }^{40 "}$.

\section{BIBLIOGRAFIA}

\section{Źródła, przekłady, komentarze}

Dante Alighieri, Boska Komedia, przeł. A. Kuciak, wstęp P. Lisicki, Poznań 2006.

G. Boccaccio, O słynnych kobietach, przeł. i oprac. P. Bańkowski, I. Grześczak, A. Szopińska, Warszawa 2013.

Liwiusz (Titus Livius Patavinus), Dzieje Rzymu od założenia miasta. Księgi I-V, przeł. A. Kościółek, wstęp J. Wolski, oprac. M. Brożek, Wrocław-Warszawa-Kraków 1968.

Owidiusz, Fasti. Kalendarz poetycki, przeł. i oprac. E. Wesołowska, Wrocław-Warszawa-Kraków 2008.

Owidiusz, Żale. Wybór, red. E. Wesołowska, przeł. M. Puk, E. Wesołowska, wstęp A. Wójcik, Poznań 2002.

Swetoniusz, Żywoty cezarów. Księga II: Boski August, edycja komputerowa: [www.zrodla. historyczne.prv.pl].

W. Szekspir, Lukrecja, w: W. Szekspir, Dzieła wszystkie, t. I: Poezje, przeł. M. Słomczyński, wstęp M. Gibińska, Kraków 2004, 219-275.

Wergiliusz, Eneida, przeł. Z. Kubiak, Warszawa 1998.

\section{Opracowania}

Baxter 2010: J. Baxter, Action Figures in Shakespeare's „,Lucrece”, „Renaissance and Reformation / Renaissance et Réforme" 33/1 (winter / hiver 2010), 81-107.

Beard 2018: M. Beard, SPQR Historia starożytnego Rzymu, Poznań 2018.

Besala 2010: J. Besala, Miłość i strach. Dzieje uczuć kobiet i mężczyzn, t. II: Cywilizacje starożytne, Poznań 2010.

Burrow 2013: C. Burrow, Shakespeare and Classical Antiquity, Oxford 2013.

Casamayor Mancisidor 2015: S. Casamayor Mancisidor, Casta, pia, lanifica, domiseda: modelo ideal de feminidad en la Roma tardorrepublicana (ss. II-I a. C.), „Ab Initio” 11 (2015), 3-23.

Grant 1978: M. Grant, Mity rzymskie, przeł. Z. Kubiak, Warszawa 1978.

Grimal 2005: P. Grimal, Miłość w starożytnym Rzymie, przeł. J.R. Kaczyński, Warszawa 2005.

Joshel 1992: S.R. Joshel, The Body Female and the Body Politic: Livy's Lucretia and Verginia, w: Pornography and Representation in Greece and Rome, red. A. Richlin, Oxford 1992, 112-130.

Jundziłł 1986: J. Jundziłł, Elementy wychowania przez prace w rzymskiej teorii wychowania w rodzinie okresu republiki, „Zeszyty Naukowe Wyższej Szkoły Pedagogicznej w Bydgoszczy” 14 (1986), 43-56.

Kamiński 2014: M. Kamiński, Poglądy Seneki na temat samobójstwa i ich znaczenie dla wspótczesnej debaty w zakresie dopuszczalności eutanazji i samobójstwa wspomaganego, „Sofia” 14 (2014), 103-119.

\footnotetext{
${ }^{40}$ Hor. Carm. III.2.13: „Słodko i zaszczytnie jest umierać za ojczyznę”.
} 
Korpanty 1980: J. Korpanty, Rzymska pochwała idealnej żony, „Meander” 35/4 (1980), 156-164. Krawczyk 2013: E.B. Krawczyk, Uwiktane. Tkanie i przędzenie a opresja kobiet $w$ literaturze starożytnej Grecji i Rzymu (maszynopis pracy magisterskiej napisanej pod kierunkiem prof. dr hab. K. Bartol), Poznań 2013.

Kruk 2012: K. Kruk, Portret żony idealnej w wygnańczej twórczości Owidiusza, „Symbolae Philologorum Posnaniensium Graecae et Latinae" XXII/1 (2012), 59-72.

Langlands 2006: R. Langlands, Sexual Morality in Ancient Rome, Cambridge 2006.

Larsson Lovén 2013: L. Larsson Lovén, Female Work and Identity in Roman Textile Production and Trade: A Methodological Discussion, w: Making Textiles in pre-Roman and Roman Times: Peoples, Places, Identities, red. M. Gleba, J. Pásztókai-Szeöke, Oxford 2013, 109-125.

Łukaszewicz-Chantry 2011: M. Łukaszewicz-Chantry, Pramatka Ewa jako postać literacka $w$ wybranych utworach renesansu. Italia, Niderlandy, Polska, „Theologica Wratislaviensia” 6 (2011), 157-169.

Łukaszewicz-Chantry 2014: M. Łukaszewicz-Chantry, Kobieta jako postać literacka w łacińskiej poezji renesansu. Italia i Polska, Wrocław 2014.

Miazek-Męczyńska 2019: M. Miazek-Męczyńska, Bohater na rozdrożu - trudny wybór między heroizmem a nikczemnościa, w: Heroica. Bohaterstwo w literaturze i kulturze europejskiej, red. A. Gawarecka, W. Szturc, E. Wesołowska, Poznań 2019, 87-104.

Mikocki 1997: T. Mikocki, Zgodna, pobożna, płodna, skromna, piękna... Propaganda cnót żeńskich w sztuce rzymskiej, Wrocław 1997.

Riess 2012: W. Riess, Rari exempli Femina: Female Virtues on Roman Funerary Inscriptions, w: A Companion to Women in the Ancient World, red. Sharon L. James, Sheila Dillon, Blackwell Publishing Ltd. 2012, 491-501.

Sapota 2009: T. Sapota, Rzymska idea samobójstwa, „Symbolae Philologorum Posnaniensium Graecae et Latinae" XIX (2009), 281-287.

Shelton 2013: J.-A. Shelton, The Women of Pliny's Letters, New York 2013.

Strunk 2014: T.E. Strunk, Rape and Revolution: Tacitus on Livia and Augustus, „Latomus” 73 (2014), 126-148.

Wesołowska 2003: E. Wesołowska, Cyceron i Seneka. Rzymska literatura wygnańcza, t. I, Poznań 2003.

Wójcik 2003: A. Wójcik, Owidiusz. Poezje znad Morza Martwego. Rzymska literatura wygnańcza, t. II, Poznań 2003.

Young 1964: A.M. Young, Echoes of Two Cultures, Pittsburgh 1964.

\section{LUCRECE AS A MODEL FOR ROMAN WOMEN. THE STORY THAT IS NOT VERY SWEET}

Sum mary

The story of Lucrece, a legendary heroine, discusses problem of the traditional female virtues connected with the Roman ancient patriarchal family. Lucrece seen from the inside (home) and outside (country) perspectives was described by Titus Livius, Publius Ovidis Naso and other ancient and Renaissance authors as an exemple of noble wife and Roman citizen, dependent on her male relatives - father and husband. This is somehow ironical, that sacrificing all her life for the family, subordinating her mind and body to the duties of daughter and wife, Lucrece regains power over herself in the last moment of her life, just after the rape, when she decides if and how to commit suicide. 